\title{
Health care expenditures after introduction of a gatekeeper and a global budget in a Swiss health insurance plan
}

\author{
Jean-François Etter, Thomas V Perneger
}

\begin{abstract}
Study objectives-To assess whether the introduction of "managed care" (capitated budget and utilisation control by general practitioners) in a Swiss health insurance plan caused a selective disenrolment of plan members, and whether it achieved its goal of reducing health care expenditures.

Design-Controlled before-after analysis of health insurance claims.

Setting-Health insurance plan of the University of Geneva, Switzerland, which introduced managed care at the end of 1992, and comparison plan, which reimbursed health care expenditures without setting a budget or controlling access.

Participants-Analysis of self selection: university plan members who accepted (3993) or refused (659) transfer to managed care. Analysis of change in expenditures: cohorts of persons continuously enrolled in the university (1575) and comparison (3384) plans in 1992 and 1993.

Main results-During 1992, the year before the transformation of the university plan, persons who refused managed care had generated $35 \%$ higher expenditures than those who accepted managed care $(p<0.001)$. Between 1992 and 1993, expenditures per member decreased by $9 \%$ in the university cohort and increased by $11 \%$ in the comparison cohort $(p=0.004)$. Technical procedures (laboratory tests, physical therapy, drugs) decreased most in the university plan. No impact on hospital admissions was detected.

Conclusions-Introduction of gatekeeping and budget management by physicians caused a favourable self selection process for the university plan. In addition, the managed care plan achieved a substantial decrease in overall health care expenditures in its first year of operation, chiefly by reducing outlays for technical procedures.
\end{abstract}

Institute of Social and Preventive Medicine, University of Geneva, Switzerland

Correspondence to: Dr J-F Etter, Institute of Social and Preventive Medicine, University of Geneva, CMU, Case Postale, CH-1211 Geneva 4 , Switzerland.

Accepted for publication 21 July 1997

Capitated budgets and control of the utilisation of health services by primary care practitioners have been successfully used for decades by the NHS to contain health care expenditures. These tools are being rediscovered by countries such as the United States and Switzerland whose health care systems have traditionally separated the provision and financing of health services. These countries, faced with runaway health care costs, increasingly encourage the development of organisations (called health maintenance organisations or managed care organisations) that provide all necessary health services to a defined population for a fixed fee. ${ }^{1}$

In Switzerland, health insurance is provided by competing private insurance plans. These indemnity plans reimburse the health care bills of their members on a fee for service basis, but have no means of influencing the utilisation of health services. This situation was changed in 1990, when a federal law authorised the creation of insurance plans "with limited choice of health care provider". A limited number of these plans were created in subsequent years. In 1992, the indemnity plan of the University of Geneva was transformed into such an organisation. Unlike traditional plans, the organisation used general practitioners to control access to specialised care (gatekeeping), and worked within a fixed annual budget managed by physician managers. These changes caused a decrease in plan members' satisfaction with medical care, but an increase in their satisfaction with insurance coverage. No impact on health status was detected one year after implementation of the new plan. ${ }^{2}$ This study examines whether or not the managed care plan achieved its goal of reducing health care costs, by analysing insurance claims data. Because some plan members refused the new system and disenrolled, we also sought to understand whether this self selection process was beneficial or detrimental to the managed care plan.

\section{Methods}

STUDY SETTING

Managed care was introduced in the group health insurance plan for students at the University of Geneva in October 1992. All members of the University plan were automatically transferred in the managed care plan. ${ }^{2}{ }^{3}$ This change was announced during the summer break, and plan members were given only one month to resign and subscribe to an individual insurance policy if they refused this modification of their insurance contract.

Two mechanisms were used to manage care 
Table 1 Organisational features of the Geneva (Switzerland) University managed care plan, as compared with indemnity insurance plans in Geneva in 1993

\begin{tabular}{|c|c|c|}
\hline Feature & Managed care plan & Indemnity insurance \\
\hline Global budget & Yes & No \\
\hline Coverage & $\begin{array}{l}\text { As specified by law on mandatory health } \\
\text { insurance }\end{array}$ & As specified by law on mandatory health insurance \\
\hline $\begin{array}{l}\text { Choice of primary care } \\
\text { physician }\end{array}$ & $\begin{array}{l}\text { Only gatekeeper affiliated with the managed } \\
\text { care plan } \\
\text { Unrestricted in case of emergency }\end{array}$ & Unrestricted \\
\hline Choice of specialist & $\begin{array}{l}\text { Only through referral from gatekeeper } \\
\text { Unrestricted for gynaecologists and } \\
\text { paediatricians }\end{array}$ & Unrestricted \\
\hline Payment of physicians & $\begin{array}{l}\text { Gatekeepers: on salary } \\
\text { Others: fee for service }\end{array}$ & Fee for service \\
\hline Monthly insurance premium & 120 Swiss francs for persons $>25$ years old & $\begin{array}{l}\text { Variable, in general } 25 \% \text { more expensive than in } \\
\text { managed care, } 165 \text { Swiss francs in comparison plan } \\
\text { for persons }>25 \text { years old }\end{array}$ \\
\hline Copayment & $\begin{array}{l}\text { None for authorised care, } 50 \% \text { for } \\
\text { specialised care not authorised by } \\
\text { gatekeeper }\end{array}$ & $\begin{array}{l}10 \% \text { for ambulatory care, up to a maximum of } 450 \\
\text { Swiss francs } \\
\text { None for hospital inpatient care }\end{array}$ \\
\hline Annual deductible & 150 Swiss francs & 150 Swiss francs \\
\hline
\end{tabular}

all other insurance plans in Geneva at this time, access to specialists was unrestricted. The second innovation was the introduction of a global budget, established on a capitation basis and managed by a group of physician managers. One thousand Swiss francs (approximately $£ 500)$ per plan member and per year were paid by the insurance company to the physician managers to reimburse all medical services. The financial risk continued to be supported by the insurance company, but a possible surplus was to be attributed to the physician managers. The physician managers did not themselves treat patients, but they supervised the work of the gatekeepers and checked the bills from independent specialists and from hospitals. The gatekeepers were young general practitioners, paid on salary by a pre-existing local clinic. In both plans and during the whole study period, health care providers, including the clinic where gatekeepers worked, were paid on a fee for service basis. All medical services, tests and other procedures in the two plans were paid according to the customary rates in Geneva (table 1).

STUDY DESIGN AND POPULATION

The study is divided in three parts.

\section{Changes in total expenditures among all plan} members

We examined refundable health care costs per plan member in the university plan and in a comparison indemnity insurance plan in 1992 (the year before the introduction of managed care) and 1993 (first year of managed care in the university plan). Members of the comparison plan were mostly workers, few were university students. ${ }^{2}$ The comparison plan was chosen for practical reasons: it was administered by the same insurance company as the university plan, and its members were also young adults living in Geneva. Participants in this part of the study consisted of all persons who were ever insured in one of the two plans in 1992 or 1993.

Changes in health care expenditures between 1992 and 1993 can be attributed both to self selection and to the impact of health care management. These two points were considered separately.

Analysis of the self selection of plan members

Fourteen per cent of members resigned in September and October 1992, when managed care was introduced in the university plan. In questionnaire surveys, they indicated that they disenrolled primarily because of the loss of free

Table 2 Refundable health care expenditures per plan member in the Geneva University insurance plan in 1992 (indemnity insurance) and 1993 (managed care), and expenditures in a comparison plan permanently under indemnity insurance (all plan members)*

\begin{tabular}{|c|c|c|c|c|c|c|c|c|}
\hline & \multicolumn{4}{|c|}{ University plan } & \multicolumn{4}{|l|}{ Comparison plan } \\
\hline & $\begin{array}{l}1992 \\
\text { Usual care }\end{array}$ & $\begin{array}{l}1993 \\
\text { Managed care }\end{array}$ & $\begin{array}{l}\text { Change } \\
(\%)\end{array}$ & $\begin{array}{l}p \text { Value on } \\
\text { changet }\end{array}$ & $\begin{array}{l}1992 \\
\text { Usual care }\end{array}$ & $\begin{array}{l}1993 \\
\text { Usual care }\end{array}$ & $\begin{array}{l}\text { Change } \\
(\%)\end{array}$ & $\begin{array}{l}p \text { Value on } \\
\text { changet }\end{array}$ \\
\hline $\begin{array}{l}\text { Average number of } \\
\text { members }\end{array}$ & 3995 & 3671 & -8.1 & - & 11637 & 16144 & +38.7 & \\
\hline Mean age (SD) & $28 \quad(8.8)$ & $28 \quad(8.4)$ & - & 0.05 & $25(14.6)$ & $26 \quad(15.5)$ & - & $<0.001$ \\
\hline Proportion of men (\%) & 48.6 & 49.3 & +0.6 & 0.55 & 47.0 & 47.5 & +0.5 & 0.41 \\
\hline $\begin{array}{l}\text { Total expenditures per } \\
\text { person }\end{array}$ & 1197 & 975 & -18.5 & $<0.001$ & 1174 & 1251 & +6.6 & 0.027 \\
\hline Expenditures for: $¥$ & & & & & & & & \\
\hline $\begin{array}{l}\text { physicians } \\
\text { drugs }\end{array}$ & $\begin{array}{l}324 \\
172\end{array}$ & $\begin{array}{l}345 \\
122\end{array}$ & $\begin{array}{l}+6.5 \\
28.9\end{array}$ & $\begin{array}{c}0.10 \\
<0.001\end{array}$ & $\begin{array}{l}400 \\
142\end{array}$ & $\begin{array}{l}394 \\
163\end{array}$ & $\begin{array}{r}-1.5 \\
+14.8\end{array}$ & $\begin{array}{c}0.46 \\
<0.001\end{array}$ \\
\hline lab tests & 98 & 55 & -43.5 & $<0.001$ & 84 & 84 & 0 & 0.89 \\
\hline$x$ rays & 26 & 18 & -30.9 & 0.02 & 15 & 21 & +40.0 & $<0.001$ \\
\hline psychiatric care & 214 & 186 & -13.0 & 0.28 & 19 & 31 & +63.2 & $<0.001$ \\
\hline physical therapy & 48 & 21 & -55.3 & $<0.001$ & 0.5 & 1 & +98.1 & 0.05 \\
\hline inpatient care & 95 & 97 & +2.6 & 0.87 & 331 & 352 & +6.3 & 0.39 \\
\hline hospital outpatient care & 122 & 78 & -36.1 & $<0.001$ & 84 & 99 & +17.9 & 0.008 \\
\hline walk in clinics & 37 & 15 & -59.7 & $<0.001$ & 54 & 57 & +5.6 & 0.42 \\
\hline
\end{tabular}

*After weighting for the number of months of presence in the plan. +Independent samples tests (underestimate the true significance, as some persons appear both in 1992 and 1993). ‡Expenditures per plan member in Swiss francs (1 Swiss franc is approximately $£ 0.4)$. 
Table 3 Comparison of persons who resigned from the Geneva University health insurance plan when managed care was introduced, and of persons who accepted managed care

\begin{tabular}{|c|c|c|c|c|}
\hline & $\begin{array}{l}\text { Resigned in } \\
\text { September/October } 1992\end{array}$ & Accepted managed care & Difference (\%) & $p$ Value on difference \\
\hline Number of plan members & 659 & 3993 & - & - \\
\hline Mean age $(\mathrm{SD})^{\star}$ & $27.6(9.5)$ & $27.8(8.8)$ & - & 0.77 \\
\hline Proportion of men $(\%)^{\star}$ & 46.3 & 49.0 & -2.7 & 0.26 \\
\hline \multicolumn{5}{|l|}{ Expenditures in 1992 for: ${ }^{\star}+$} \\
\hline physicians & 440 & 319 & +38 & $<0.001$ \\
\hline drugs & 259 & 166 & +56 & $<0.001$ \\
\hline lab tests & 136 & 96 & +42 & 0.003 \\
\hline$x$ rays & 33 & 26 & +27 & 0.37 \\
\hline psychotherapy & 236 & 219 & +8 & 0.77 \\
\hline physical therapy & 75 & 46 & +63 & 0.01 \\
\hline hospital inpatient care & 121 & 94 & +28 & 0.40 \\
\hline hospital outpatient care & 135 & 125 & +8 & 0.65 \\
\hline walk in clinics & 52 & 36 & +44 & 0.06 \\
\hline Total expenditures in $1992^{\star}$ & 1599 & 1185 & +35 & $<0.001$ \\
\hline Total expenditures in $1991 \neq$ & 1283 & 1058 & +21 & 0.01 \\
\hline Total expenditures in $1990 \ddagger$ & 1122 & 983 & +14 & 0.12 \\
\hline Total expenditures in $1989 \ddagger$ & 797 & 726 & +10 & 0.31 \\
\hline
\end{tabular}

*Weighted for duration of affiliation in 1992. †Expenditures in Swiss francs (1 Swiss franc is approximately $£ 0.4$ ). $\ddagger$ Weighted for duration of affiliation during the corresponding year.

choice of physician and because they feared that the managed care plan would provide care of inferior quality. ${ }^{4}$ We compared those who resigned ("resigners") to those who joined the managed care plan ("joiners"), in terms of past health care expenditures.

\section{Cohort study}

To remove the effect of self selection, we followed up cohorts of persons who remained continuously insured in the university plan or in the comparison plan in 1992 and 1993. Expenditures during 1992 were compared with expenditures during 1993. Participants were 18-44 years old in 1992 and had been members of their respective plan from 1 July 1991 to 31 December 1993. Only persons who enrolled at least six months before the beginning of the period under analysis were included, to avoid errors resulting from the low utilisation of health services among recently registered persons during their first months of membership.

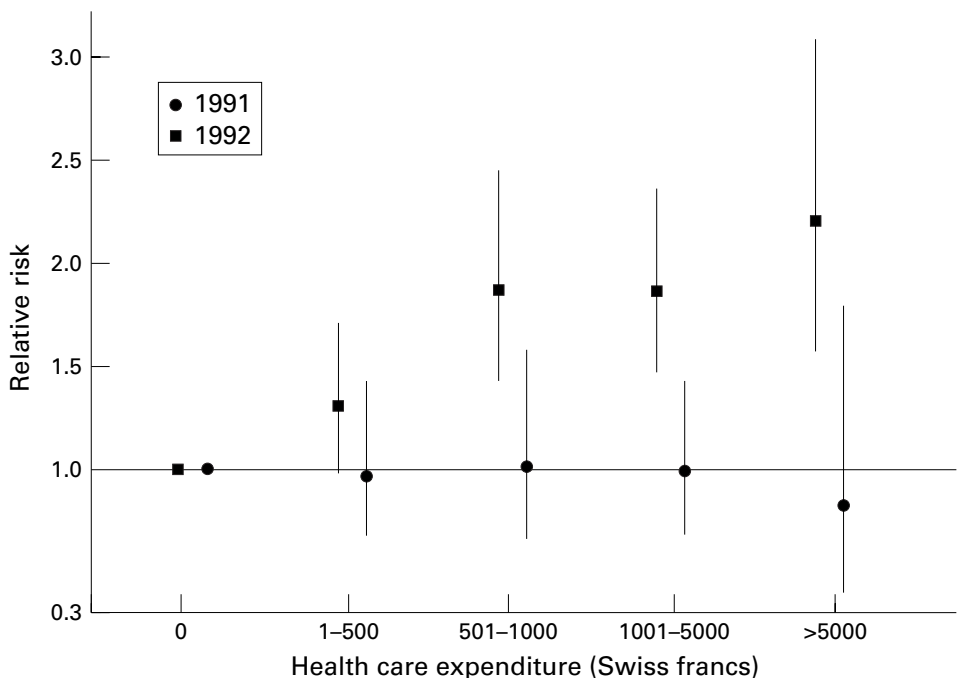

Figure 1 Relative risk (95\% confidence intervals) of resigning from the Geneva University health insurance plan in September/October 1991 (round symbols) and in September/October 1992 (after the introduction of managed care, square symbols), according to the level of health care expenditures during the corresponding year.
DATA

We analysed the database used by the insurance company for its administrative management. For each person, the database indicated birth date and sex, the dates when affiliation in the insurance plan began and ended, and the refundable expenditures for each year from 1989 to 1993 . Insurance coverage was the same in the university plan before and after the introduction of managed care and in the comparison plan. Refundable services were as specified by the Swiss law on health insurance. Data were entered in the computer files by the same personnel for both plans, at the office of the insurance company. Prices for health services were identical in the two plans. Expenditure data in the two plans during the whole study period were therefore comparable.

\section{ANALYSIS}

\section{Comparing all plan members}

Because some members were not insured during the whole year, average annual costs per person and proportions of plan members who generated expenditures were computed after weighting for the number of months of affiliation in the plan (for 12 months of presence, weight $=1$; for six months of presence, weight $=0.5$, etc). In each group, independent samples $t$ tests were used to assess change in expenditures between 1992 and 1993. As expenditures in 1992 and 1993 were not entirely independent (many persons were present both in 1992 and 1993), the use of independent samples $t$ tests is conservative and underestimates the true statistical significance of change.

\section{Self selection study}

Annual expenditures from 1989 to 1992 among "resigners" and "joiners" were compared, for each expenditure category. Comparisons of resigners and joiners and computation of the relative risk of resigning were weighted for the number of months spent in the insurance plan during each year. 
Table 4 Refundable health care expenditures for two cohorts of plan members: persons permanently insured in 1992 and 1993 in the Geneva University insurance plan and in a comparison indemnity plan

\begin{tabular}{|c|c|c|c|c|c|c|c|c|c|}
\hline & \multicolumn{4}{|c|}{ University cohort $(n=1575)$} & \multicolumn{4}{|c|}{ Comparison cohort $(n=3384)$} & \multirow[b]{2}{*}{$\begin{array}{l}p \text { Value on difference } \\
\text { in changet }\end{array}$} \\
\hline & $\begin{array}{l}1992 \\
\text { Usual care }\end{array}$ & $\begin{array}{l}1993 \\
\text { Managed care }\end{array}$ & $\begin{array}{l}\text { Change } \\
(\%)\end{array}$ & $\begin{array}{l}p \text { Value on } \\
\text { change* }\end{array}$ & $\begin{array}{l}1992 \\
\text { Usual care }\end{array}$ & $\begin{array}{l}1993 \\
\text { Usual care }\end{array}$ & Change (\%) & $\begin{array}{l}\text { p Value on } \\
\text { change }\end{array}$ & \\
\hline Total expenditures & 1461 & 1332 & -8.8 & 0.015 & 1847 & 2058 & +11.4 & 0.008 & 0.004 \\
\hline \multicolumn{10}{|l|}{ Expenditures for: $\ddagger$} \\
\hline physicians & 353 & 400 & +13.4 & 0.004 & 565 & 584 & +3.4 & 0.22 & 0.29 \\
\hline drugs & 194 & 162 & -16.5 & 0.001 & 198 & 247 & +24.9 & $<0.001$ & $<0.001$ \\
\hline lab tests & 109 & 73 & -32.8 & $<0.001$ & 140 & 144 & +2.9 & 0.52 & 0.001 \\
\hline$x$ rays & 26 & 23 & -11.1 & 0.49 & 25 & 34 & +31.9 & 0.024 & 0.065 \\
\hline psychotherapy & 333 & 337 & +1.1 & 0.88 & 36 & 52 & +42.6 & 0.021 & 0.56 \\
\hline physical therapy & 53 & 32 & -40.1 & $<0.001$ & 1 & 1 & 0 & 0.93 & $<0.001$ \\
\hline hospital inpatient care & 116 & 140 & +20.7 & 0.44 & 619 & 681 & +9.9 & 0.35 & 0.61 \\
\hline hospital outpatient care & 165 & 97 & -41.1 & $<0.001$ & 112 & 153 & +37.4 & 0.001 & $<0.001$ \\
\hline walk in clinics & 42 & 21 & -50.0 & $<0.001$ & 79 & 84 & +7.5 & 0.30 & 0.004 \\
\hline
\end{tabular}

$\star$ Paired $t$ test. $\dagger t$ Test on difference between plans in change between 1992 and 1993, adjusted for age and sex. $\ddagger$ Expenditures per plan member in Swiss francs (1 SFr is approximately $£ 0.4$ ).

Cohort study

(a) Health care expenditures per member - Within each cohort, paired $t$ tests were used to assess changes in annual expenditures per person between 1992 and 1993. For each category of expenditures, we computed individual differences between 1992 and 1993 and compared the two cohorts in analysis of covariance models, adjusting for age and sex.

(b) Proportion of persons who generated expenditures-Within each plan, changes between 1992 and 1993 in the proportions of plan members who generated expenditures were assessed with the McNemar's test for matched data. ${ }^{6}$ The two cohorts were compared for changes between 1992 and 1993 by testing the heterogeneity of the McNemar's matched odds ratios across groups. ${ }^{7} \mathrm{McNe}-$ mar's odds ratio equals $b / c$ where $b=$ baseline non-users who generated expenditures at follow up, and $\mathrm{c}=$ baseline users who did not generate expenditures at follow up. The test for heterogeneity of McNemar's odds ratios compares $b / c$ (university plan) to $b^{\prime} / c^{\prime}$ (comparison plan), using the ratio of odds ratios, $\mathrm{bc}^{\prime} / \mathrm{b}^{\prime} \mathrm{c}^{7}$ This analysis was adjusted for age and sex in logistic regression models.

\section{Results}

CHANGES IN EXPENDITURES AMONG ALL PLAN MEMBERS

Between 1992 and 1993, expenditures decreased by $19 \%$ in the university plan and increased by $7 \%$ in the comparison plan (table 2 ). The proportion of plan members who generated expenditures decreased from $68 \%$ to $64 \%$ $(p<0.001)$ in the university plan and remained unchanged at $66 \%$ in the comparison plan.

Only four "resigners" of the university plan joined the control plan. This small number of transfers is unlikely to have had an impact on expenditures in the control plan.

SELF SELECTION OF PLAN MEMBERS

Resigners and joiners were similar according to age and sex (table 3). In 1992, resigners had caused 35\% higher expenditures per person than joiners, and more resigners $(80 \%)$ than joiners $(69 \%, \mathrm{p}<0.001)$ had generated costs. Expenditures were higher among resigners than among joiners in each of the years 1989 to 1992. The difference between the two groups was smallest in 1989, and then increased progressively for each subsequent year (table 3).

The probability of resigning from the university plan after the introduction of managed care increased progressively with the level of expenditures in the previous year (fig 1, square symbols). To test the hypothesis that the association between health care expenditures and resignation was specific to September and October 1992, when managed care was introduced, we repeated the same analysis for the preceding year, 1991. The probability to resign in September or October 1991 was not associated with the level of health care expenditures in 1991 (fig 1 , round symbols).

\section{IMPACT OF MANAGED CARE ON INSURANCE} CLAIMS (COHORT STUDY)

Total expenditures decreased by $9 \%$ in the university cohort and increased by $11 \%$ in the

Table 5 Proportions of persons who generated refundable health care expenditures, in two cohorts of plan members: persons permanently insured in 1992 and 1993 in the Geneva University insurance plan and in a comparison indemnity plan

\begin{tabular}{|c|c|c|c|c|c|c|c|c|c|}
\hline \multirow[b]{2}{*}{$\begin{array}{l}\text { Proportions of persons who } \\
\text { generated expenditures for: }\end{array}$} & \multicolumn{4}{|c|}{ University cohort $(n=1575)$} & \multicolumn{4}{|c|}{ Comparison cohort $(n=3384)$} & \multirow[b]{2}{*}{$\begin{array}{l}p \text { Value on difference } \\
\text { in changet }\end{array}$} \\
\hline & $\begin{array}{l}1992 \\
\text { Usual care }\end{array}$ & $\begin{array}{l}1993 \\
\text { Managed care }\end{array}$ & Difference (\%) & $\begin{array}{l}p \text { Value on } \\
\text { difference }\end{array}$ & $\begin{array}{l}1992 \\
\text { Usual care }\end{array}$ & $\begin{array}{l}1993 \\
\text { Usual care }\end{array}$ & Difference (\%) & $\begin{array}{l}\text { p Value on } \\
\text { difference }\end{array}$ & \\
\hline any expenditure & 73.1 & 71.2 & -1.9 & 0.16 & 71.9 & 74.4 & +2.5 & 0.002 & 0.002 \\
\hline physicians & 55.0 & 62.4 & +7.4 & $<0.001$ & 59.6 & 62.2 & +2.6 & 0.003 & 0.015 \\
\hline drugs & 57.1 & 55.4 & -1.7 & 0.050 & 58.5 & 62.3 & +3.8 & $<0.001$ & $<0.001$ \\
\hline lab tests & 32.8 & 26.3 & -6.5 & $<0.001$ & 39.7 & 40.8 & +1.1 & 0.28 & $<0.001$ \\
\hline$x$ rays & 5.7 & 5.1 & -0.6 & 0.51 & 5.1 & 6.9 & +1.8 & $<0.001$ & 0.014 \\
\hline psychotherapy & 10.0 & 9.8 & -0.2 & 0.92 & 2.6 & 4.0 & +1.4 & $<0.001$ & 0.002 \\
\hline physical therapy & 7.0 & 4.3 & -2.7 & $<0.001$ & 0.3 & 0.3 & 0 & 1.00 & 0.25 \\
\hline hospital inpatient care & 5.6 & 6.9 & +1.3 & 0.11 & 10.5 & 12.2 & +1.7 & 0.016 & 0.76 \\
\hline hospital outpatient care & 27.5 & 20.1 & -7.4 & $<0.001$ & 23.4 & 25.2 & +1.8 & 0.048 & $<0.001$ \\
\hline walk in clinics & 12.3 & 6.2 & -6.1 & $<0.001$ & 15.8 & 16.1 & +0.3 & 0.68 & $<0.001$ \\
\hline
\end{tabular}

${ }^{\star} \mathrm{McNemar}$ test. $†$ Test for difference between insurance plans in change over time, homogeneity of McNemar odds ratio adjusted for age and sex. 
comparison cohort between 1992 and 1993 (table 4). The proportion of persons who generated expenditures remained stable in the university cohort, but increased in the comparison cohort (table 5).

Between 1992 and 1993, expenditures for hospital inpatient care remained unchanged in both cohorts. Expenditures for psychotherapy remained unchanged in the university cohort but increased in the comparison cohort. In the university cohort, expenditures for technical services (drugs, laboratory tests, physical therapy) decreased between 1992 and 1993, whereas similar expenditures increased or remained unchanged in the comparison cohort. Expenditures for outpatient treatments in hospital clinics and for care in walk in clinics (outpatient clinics open 24 hours a day) decreased in the university cohort, but expenditures under the heading "physicians" increased.

In the university cohort, expenditures decreased by $17.3 \%$ among men between 1992 and $1993(\mathrm{p}=0.001)$, but remained unchanged among women $(-3.7 \%, p=0.44)$. Similarly, the proportion of persons who generated expenditures decreased among men (from $66 \%$ to $62 \%, \mathrm{p}=0.057)$ but remained stable among women $(80 \%, \mathrm{p}=0.93)$. In the comparison cohort, expenditures increased similarly among men and women.

\section{Discussion}

The introduction of gatekeeping by general practitioners and budget management by physicians on a capitation basis in the insurance plan for students at the University of Geneva had two main effects: (1) a self selection process favourable to the insurance company, and (2) a decrease in health care expenditures among persons continuously enrolled in the plan.

\section{SELF SELECTION OF PLAN MEMBERS}

The decision to resign from the university plan when managed care was introduced was strongly influenced by the level of use of health services during the previous year. This analysis confirms results of questionnaire surveys conducted in the same population. ${ }^{34}$ Lower pre-enrolment use of health services has been observed in most, ${ }^{8-11}$ but not all studies that investigated self selection processes between managed care plans and indemnity insurance systems. ${ }^{12}{ }^{13}$ Our study brings a new insight by showing that the choice between the two systems was more strongly influenced by recent use of health services than by use during the preceding years. Because of regression toward the mean, it is possible that the long term tendency to use health services is a better predictor of future use than recent utilisation. ${ }^{14}$ If so, selection studies based on measures of recent use of health services would overestimate the impact of self selection on future costs.

DECREASE IN HEALTH CARE EXPENDITURES

The decrease in total expenditures in the Geneva University plan was particularly important when compared with the increase
KEY POINTS

- Gatekeeping by GPs and budget management by physicians produced important decreases in health care expenditures in Swiss insurance plan members.

- Decreases in expenditures were achieved chiefly by reducing technical procedures (laboratory tests, drugs, physical therapy).

- The introduction of managed care caused selective disenrollment of the more expensive plan members.

observed in the comparison group. Changes in health care expenditures between 1992 and 1993 were only marginally explained by inflation in prices of health services (2\% between 1992 and 1993). ${ }^{15}$ Managed care affected health services utilisation in two ways: the use of technical procedures (laboratory tests, medications, physical therapy) decreased, and patient visits were transferred from hospital outpatient clinics and walk in clinics to the category "physicians". The latter category includes both gatekeepers and specialists, but questionnaire surveys conducted in the same population indicated that visits to specialists decreased in the university plan after the introduction of managed care, whereas visits to general practitioners increased..$^{16} \mathrm{~A}$ decrease in visits to specialists after the introduction of gatekeeping was also described in the US. ${ }^{17}$ The decrease in the use of technical procedures obtained in Geneva is consistent with results obtained by several American managed care plans. ${ }^{1819}$

Comparison between Switzerland and other European countries is more problematic, as few other countries rely so heavily on private insurance companies and private health care providers. ${ }^{20-22}$ However, the Geneva managed care plan and the UK system share some characteristics, in particular budget control by physicians and control by general practitioners of access to specialised care. There is no evidence that the UK fundholding system encouraged a shift from specialists to general practitioners. ${ }^{23-25}$ Decreases in costs for medications were described in some ${ }^{26} 27$ but not all ${ }^{28}$ studies of fundholding. The decrease in technical procedures in the Geneva managed care plan may have been caused by the particular management style of physicians in this plan. Gatekeepers said that more thorough explanations often enabled them to avoid unnecessary technical procedures, and that coordinating expensive procedures and tests performed by specialists may have reduced the number of duplicated tests. ${ }^{5}$ Finally, gatekeepers prescribed generic drugs whenever possible. Prescription of generic drugs also explains why costs for medications were reduced in some UK fundholding practices. ${ }^{29}$

Expenditures for inpatient care were higher in the comparison plan than in the university plan. This difference was much more important among women than among men, probably 
because hospitalisation for childbirth was more frequent in the control group than among students of the university group. Hospital expenditures remained unchanged after the introduction of managed care in the Geneva plan, which conflicts with results observed in the United States. ${ }^{1}{ }^{30}{ }^{31}$ In the UK, the impact of fundholding on hospital costs is still unclear, but it has been suggested that differences in inpatient expenditures between fundholding and non-fundholding practices are explained by fundholding practices having received more money from the NHS than non-fundholding practices. ${ }^{32}$ The Geneva managed care plan had little control over hospital admissions, as it served mostly young adults, for whom most admissions occur in emergency or for childbirth. In addition, because Swiss hospitals are largely subsidised by the government, hospital charges reimbursed by insurance companies represent only about a third of the actual costs. There is therefore no incentive for any insurance plan to avoid hospitalisation and pay instead for unsubsidised ambulatory care.

Expenditures for psychotherapy were much higher in the university plan than in the comparison plan. Interviews with gatekeepers and physician managers indicated that psychological problems were frequent among members of the university plan, probably because many of them were foreign students facing social integration problems. Gatekeepers said that they did not want to take risks by restricting access to psychotherapy. ${ }^{5}$ Persistence of higher expenditures for psychotherapy after introduction of managed care conflicts with results from American studies, which showed that managed care plans had lower mental health care costs than fee for service plans, even after controlling for level of mental health of plan members. ${ }^{34}{ }^{34}$ In the UK, it has been suggested that ambulatory mental health care visits increased more in fundholding than in nonfundholding practices. ${ }^{35}$

Expenditures in the university cohort decreased sharply among men but remained stable among women, which suggests that gatekeeping was an effective means of cost control. As free access to gynaecologists was maintained, women had an alternative unrestricted access to health services.

This study has several limitations. Expenditures were recorded for each calendar year, but the change in insurance contracts occurred during the year, in October 1992. Therefore, the first 2.5 months of the managed care plan were attributed to 1992 , even though in our computations, we considered that the whole year 1992 was under usual care. This caused an overestimation of the effect of self selection, because expenditures of joiners probably decreased already during the 2.5 months under managed care in 1992. For the same reason, we probably underestimated the impact of managed care, as the initial decrease in expenditures was attributed to the baseline year.

The generalisability of our findings is limited because members of both plans were young and urban, and because the conditions of the introduction of managed care in the university plan were unusual (all plan members were automatically transferred into the managed care plan). However, most studies of innovations in health care management are case studies with limited generalisability. Also, our study was limited to the first year of existence of the Geneva managed care plan, which may not be representative of long term performance.

Finally, as in all non-randomised studies, the danger exists that an unmeasured confounder explains between group differences. It is hard to see what confounder would explain changes in health care expenditures over time. The availability of a control group enabled us to take into account historic trends. In particular, health insurance premiums increased in 1993 for all young adults in Geneva, as a result of a new law that imposed equal premiums for adults of all ages. This change may have modified health care seeking behaviours.

In summary, this paper suggests that in Switzerland, managed care plans have a potential to be unfair competitors to other health care plans, because they may attract "low risk" consumers. However, in addition to causing self selection, gatekeeping and budget management by physicians have a potential for controlling expenditures. The comparison of our results with previously published studies show that the effects of health care management tools depend on the system in which they are implemented. Comparisons between different countries have a potential to enhance our understanding of the effects of these innovations.

Part of this work was presented at the conference of the Latin association for the analysis of health systems (ALASS), Geneva, Switzerland, June 1996.

Funding: this research was funded by the Institute of Social and Preventive Medicine of the University of Geneva, by the insurance company Avenir, and by grants 3233-32609.91 and 32-39692.93 from the Swiss National Science Foundation. Conflicts of interest: none.

1 Miller RH, Luft HS. Managed care plan performance since 1980, a literature analysis. $\mathscr{F} A M A$ 1994;271:1512-19

2 Perneger TV, Etter JF, Rougemont A. Switching Swiss enrollees from indemnity health insurance to managed care: the effect on health status and satisfaction with care. Am F Public Health 1996;86:388-93.

3 Perneger TV, Allaz AF, Etter JF, et al. Mental health and choice between managed care and indemnity health insurance. Am F Psychiatry 1995;152:1020-5.

4 Etter JF, Perneger TV, Rougemont A. Self-selection of enrollers at the creation of a managed care organization. Eur F Public Health 1995;5:157-62.

5 Etter JF, Perneger TV. Quantitative and qualitative assessment of patient satisfaction in a managed care plan. Evaluation and Program Planning 1997;20:129-35.

6 Fleiss JL. Statistical methods for rates and proportions. 2nd ed. New York: John Wiley, 1981.

7 Breslow NE, Day NE. Statistical methods in cancer research. Volume I: the analysis of case-control studies. Lyon, France: Volume I: the analysis of case-control studies. Lyon, Fran
International Agency for Research on Cancer, 1980.

8 Jackson-Beeck M, Kleinman JH. Evidence for self-selection Jackson-Beeck $\mathrm{M}$, Kleinman $\mathrm{JH}$. Evidence for self-selection
among health maintenance organization enrollers. $\mathscr{f} A M A$ 1983;250:2826-9.

9 Lairson DR, Herd AJ. The role of health practices, health status, and prior health care claims in HMO selection bias. Inquiry 1987;24:276-84.

10 Strumwasser I, Paranjpe NV, Ronis DL. The triple option choice: self-selection bias in traditional coverage, HMOs, and PPOs. Inquiry 1989;26:432-41

11 Billi JE, Wise CG, Sher SI, et al. Selection in a preferred provider organization enrolment. Health Serv Res 1993;28: 563-75.

12 Broida $\mathrm{JH}$, Lerner $\mathrm{M}$, Lohrenz $\mathrm{FN}$, et al. Impact of membership in an enrolled, prepaid population on utilization of health services in a group practice. $N$ Engl $\mathcal{f ~ M e d}$ 1975;292:780-3.

13 Roghman KJ, Gavett WJ, Sorensen AA, et al. Who chooses prepaid medical care: survey results from two marketings of three new prepayment plans. Public Health Rep 1975;90: three new 
14 Riley G, Rabey E, Kasper J. Biased selection and regression toward the mean in three Medicare HMO demonstrations. A survival analysi
$1989 ; 27: 337-51$

15 Office Cantonal de la Statistique. La santé en chiffres. Genève: OCSTAT, Etudes et documents No 19, 1995.

16 Etter JF, Perneger TV. Introducing managed care in Swizerland: impact on self-reported use of health services Public Health 1997;641:417-22.

17 Martin DO, Diehr P, Price KF, et al. Effect of a gatekeeper plan on health services use and charges: a randomized trial. Am F Public Health 1989;79:1628-32.

18 Hurley RE, Freund DA, Gage BA. Gatekeeper effects on patterns of physician use. F Fam Pract 1991;32:167-74.

19 Lohr KN, Brook RH, Kamberg CJ, et al. Use of medical care in the Rand Health Insurance experiment, use of selected drugs and procedures. Med Care 1986;24:S39-50.

20 Centre de recherches international pour la santé. L'Europe de la santé, un enjeu incontournable. Paris: CRIS, 1993.

21 Immergut EM. Health politics, interests and institutions in Western Europe. Cambridge: Cambridge University Press, 1992.

22 Organisation for Economic Co-operation and Development OECD health systems. Vol. 1. Paris: OECD, 1993.

23 Coulter A, Bradlow J. Effect of NHS reforms on general practitioners' referral patterns. BMF 1993;306:433-7.

24 Surender R, Bradlow J, Coulter A, et al. Prospective study of trends in referral patterns in fundholding and nonfundholding practices in the Oxford region, 1990-4. BMF 1995;311:1205-8.

25 Kammerling RM, Kinnear A. The extent of the two tier service for fundholders. BMF 1996;312:1399-401.
26 Maxwell M, Heaney D, Howie JG, et al. General practice fundholding: observations on prescribing patterns and
costs using the defined daily dose method. BMF 1993;307: costs using
$1190-4$.

27 Harris CM, Scrivener G. Fundholders' prescribing costs: the first five years. BMF 1996;313:1531-4

28 Stewart-Brown S, Surender R, Bradlow J, et al. The effects of fundholding in general practice on prescribing habits there years after introduction of the scheme. BMf 1995;311:1543-7.

29 Wilson RPH, Buchan I, Waley T. Alterations in prescribing by general practitioner fundholders: an observational study. BM7 1995;311:1347-50.

30 Bradbury RC, Golec JH, Stearns FE. Comparing hospital length of stay in independent practice HMOs and traditional insurance programs. Inquiry 1991;28:87-93.

31 Manning W, Leibowitz A, Goldberg GA, et al. A controlled trial of the effect of a prepaid group practice on use of services. N Engl f Med 1984;310:1505-10.

32 Dixon J, Dinwoodie M, Hodson D, et al. Distribution of NHS funds between fundholding and non-fundholding practices. BMF 1994;309:30-4.

33 Norquist GS, Wells KB. How do HMOs reduce outpatient mental health care costs? Am f Psychiatry 1991;148:96101.

34 Wells KB, Hosek SD, Marquis MS. The effects of preferred provider options in fee-for-service plans on use of outpatient mental health services by three employee groups. Med Care 1992;30:412-27.

35 Corney RH. Links between mental health care professionals and general practices in England and Wales: the impact of GP fundholding. Br f Gen Pract 1996;46:221-4. 